\title{
Gross Anatomy of the Heart of Pampas Deer (Ozotoceros bezoarticus, Linnaeus 1758)
}

\author{
Noelia Vazquez ${ }^{1}$ Dellis Dos Santos ${ }^{1}$ William Pérez ${ }^{1}$ \\ ${ }^{1}$ Division of Anatomy, Facultad de Veterinaria, Universidad de la \\ República (UDELAR), Lasplaces, Montevideo, Uruguay \\ 2 Department of Genetics and Animal Breeding, Laboratorio de \\ Análisis Genéticos de Animales Domésticos, Facultad de Veterinaria, \\ Universidad de la República (UDELAR), Lasplaces, Montevideo, \\ Uruguay \\ ${ }^{3}$ Imaging Department, Centro Hospital Veterinario, Facultad de \\ Veterinaria, Universidad de la República (UDELAR), Lasplaces, \\ Montevideo, Uruguay \\ J Morphol Sci 2019;36:190-195.
}

\begin{abstract}
Address for correspondence Noelia Vazquez, MSc DMV, Área de Anatomía, Facultad de Veterinaria, Universidad de la República (UDELAR), Alberto Lasplaces 1550, CP 11600, Montevideo, Uruguay (e-mail: noeliavz85@gmail.com).
\end{abstract}

\begin{abstract}
Keywords

- atrium

- cervidae

- coronary artery

The pampas deer belongs to the Cervidae family (Artiodactyla order). It used to be a common and abundant species that had a wide distribution. However, at the end of the $19^{\text {th }}$ century, the populations were decimated. In general, the hearts of mammals share many similarities, but size, shape, position, vessel organization and branching can vary among species. The objective of the present study was to describe the macroscopic morphology, topography and irrigation of the heart of the pampas deer. The anatomical study was conducted with 20 animals that had died of natural causes. The animals were studied by simple dissection. All animals had colored latex injected into one of the common carotid arteries to facilitate the visualization. The position of the heart, with a $45^{\circ}$ axis, the presence of a double sternopericardial ligament, and the bilateral cardiac circulation were some of the notable findings.
\end{abstract}

\section{Introduction}

The pampas deer belongs to the Cervidae family (Artiodactyla order), which also includes around 40 species of deer, elk and caribou. The pampas deer used to be a common and abundant species that had a wide distribution. However, at the end of the $19^{\text {th }}$ century, the populations were decimated, and their habitat was fragmented. ${ }^{1}$ The pampas deer is a medium-sized deer that weighs between 20 to $40 \mathrm{~kg}$ and has a wide variation in body size. The color of the fur varies geographically according to the subspecies, going from tan to reddish-brown. $^{2}$

The basic anatomical knowledge provides the necessary path to be able to perform and improve any medical, surgical, technical or conservationist procedure in pampas deer. It is also the fundamental pillar for physiological or physiopathological studies.

received

July 24, 2018

accepted

April 14, 2019
In general, the hearts of mammals share many similarities, but size, shape, position, vessel organization and branching can vary considerably among species. ${ }^{3}$ The presence or absence of certain anatomical structures in the heart may vary in domestic species. The arterial circulation of the heart also varies among different species, and it can be of the right or left type, depending on whether the interventricular branch originates from the left or right coronary arteries. Cardiac anatomic studies and those related to heart vessels have been performed on both domestic and wild species. ${ }^{4-11}$

The studies conducted with Ozotoceros bezoarticus regarding arterial blood supply include the arterial supply of the head and neck, ${ }^{12}$ arterial irrigation of the pelvis and the pelvic limb, ${ }^{13}$ arterial distribution of the aortic arch, ${ }^{9}$ arterial vascularization of the adrenal glands, ${ }^{8}$ anatomy of the female reproductive system, ${ }^{14}$ anatomy of the male

Copyright @ 2019 by Thieme Revinter

Publicações Ltda, Rio de Janeiro, Brazil
License terms

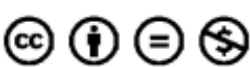


reproductive system, ${ }^{15}$ and irrigation of the stomach and intestine. ${ }^{16}$ According to our knowledge, there is no anatomical description of the heart of the pampas deer. The objective of the present study was to describe the macroscopic morphology, topography and irrigation of the heart of the pampas deer.

\section{Materials and Methods}

\section{Animals}

The anatomical study was carried out with 20 animals that had died of natural causes, were free of pathologies that affected the circulatory system, and came from Estación de Cría de Fauna Autóctona de Pan de Azúcar, Maldonado, Uruguay (ECFA, $34^{\circ} 3^{\prime} \mathrm{S}, 55^{\circ} 1^{\prime}$ OR). The animals that died in the ECFA were collected by local personnel and frozen at $-20^{\circ} \mathrm{C}$ to be subsequently studied. A total of 8 adult females, 3 adult males and 9 offspring were dissected. The average weight was $13.45 \pm 1.3 \mathrm{~kg}$.

\section{Methods}

The method of study of the animals was simple dissection. All animals had colored latex injected into one of the common carotid arteries to facilitate the visualization. In order to perform this procedure, the skin was incised in the ventral region of the neck, lateral to the trachea, and the muscles of the region were isolated to give access to one of the common carotid arteries. A catheter (caliber according to the volume of the vessel) was placed inside the artery, and red latex was injected until the femoral arteries could be visualized. The animals were placed for 48 hours in a cold chamber (at $3^{\circ} \mathrm{C}$ ) to allow adequate coagulation of the latex.

The dissection was performed in stages. First, the muscles of the costal wall and the intercostal muscles were removed to visualize the topography of the thorax. Then, the ribs were removed, and the in situ dissection of the heart and its vessels was performed. Finally, the heart was removed by incising the large vessels, and then a cut was made parallel to the interventricular grooves to visualize the internal structures.

The photographs were taken with a Nikon (Minato, Tokyo, Japan) digital camera and macro lens. They were then edited using the GIMP (GNOME Foundation, Orinda, CA, US) software, version 2.8.14. The terms used for the description are in agreement with the Nomina Anatomica Veterinaria. $^{17}$

The specimens were handled and treated according to the Ethics Board guidelines of Universidad de la República (Montevideo, Uruguay).

\section{Results}

The heart was lodged in the middle mediastinum. Two thirds of the heart were to the left of the median plane of the body, and its axis formed a $45^{\circ}$ angle (-Figs. 1, 2). The apex was close to the sternum at the level of the sixth intercostal space. The projection of the heart on the thorax wall extended

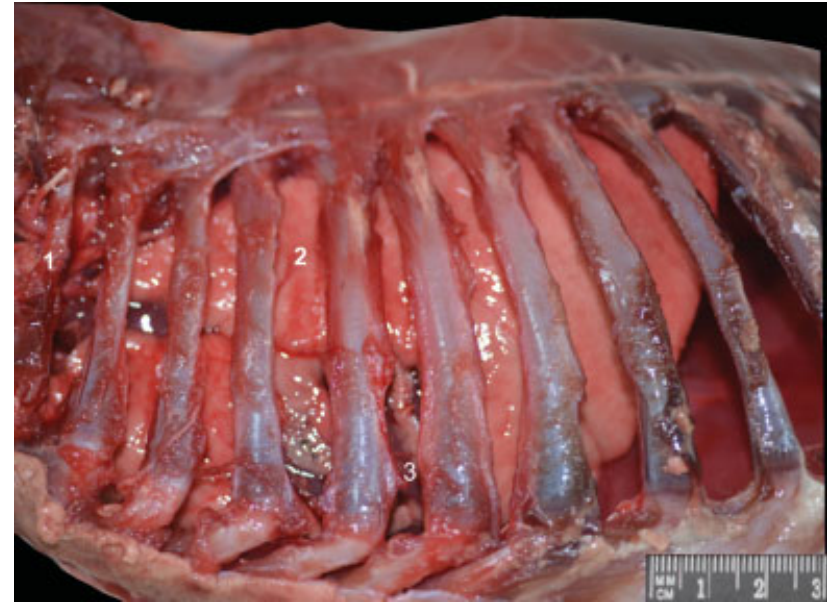

Fig. 1 Left lateral view of the thorax, after the removal of the costal muscles. 1: first rib; 2: lung; 3: heart.

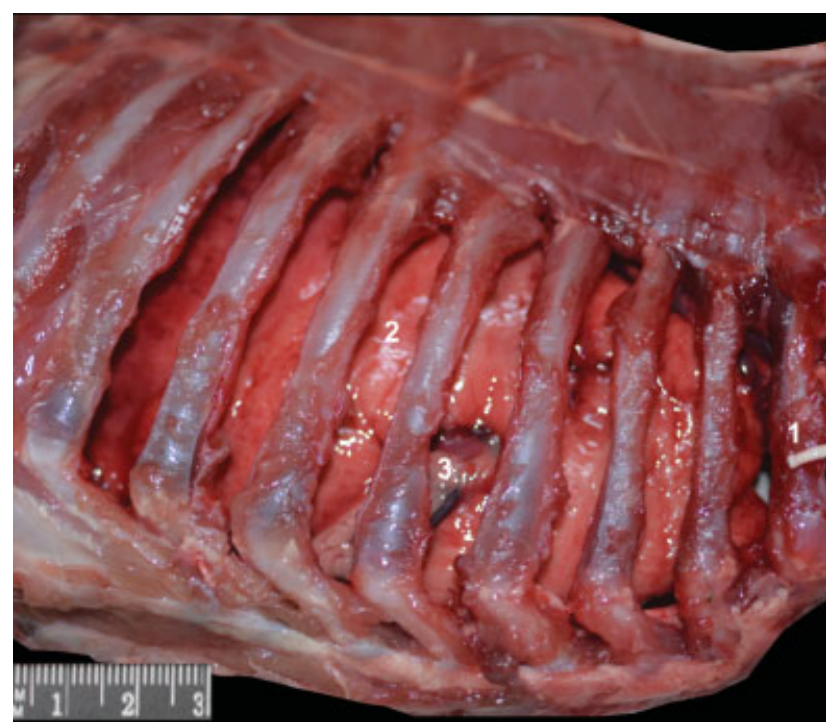

Fig. 2 Right lateral view of the thorax, after the removal of the costal muscles. 1: first rib; 2: lung; 3 : heart.

between the third and sixth intercostal spaces on the left side (-Fig. 3), and between the fifth and sixth on the right side (-Fig. 4). The heart was covered by the pericardium (-Figs. $3,4)$. A double sternopericardial ligament helped the fibrous pericardium fix the heart to the sternum (-Fig. 5). No phrenicopericardial ligament was observed.

The heart was transversely elongated, accompanying the

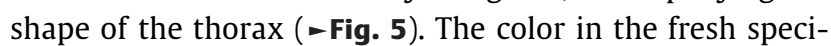
mens was light brownish-red. The grooves and vessels were covered by a small amount of subepicardial adipose tissue, beige and with medium consistency (-Figs 3, 4, 5). The consistency of the myocardium was firm, although the right side of the heart was depressible, while the left side was more resistant to pressure.

Both atria were separated from each other by the interatrial septum. The right atrium was the most voluminous. Each atrium had a blind diverticulum, the auricle. In the right 


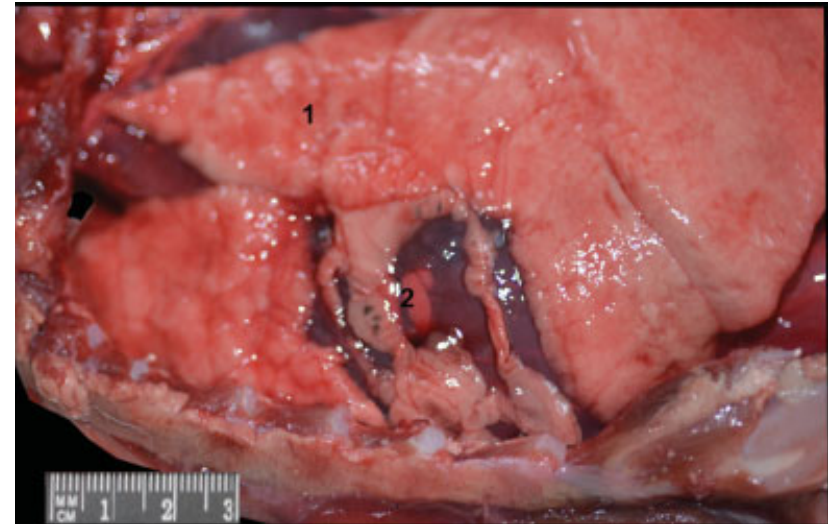

Fig. 3 Left lateral view of the thorax, after the removal of the ribs. 1: lung; 2: heart.

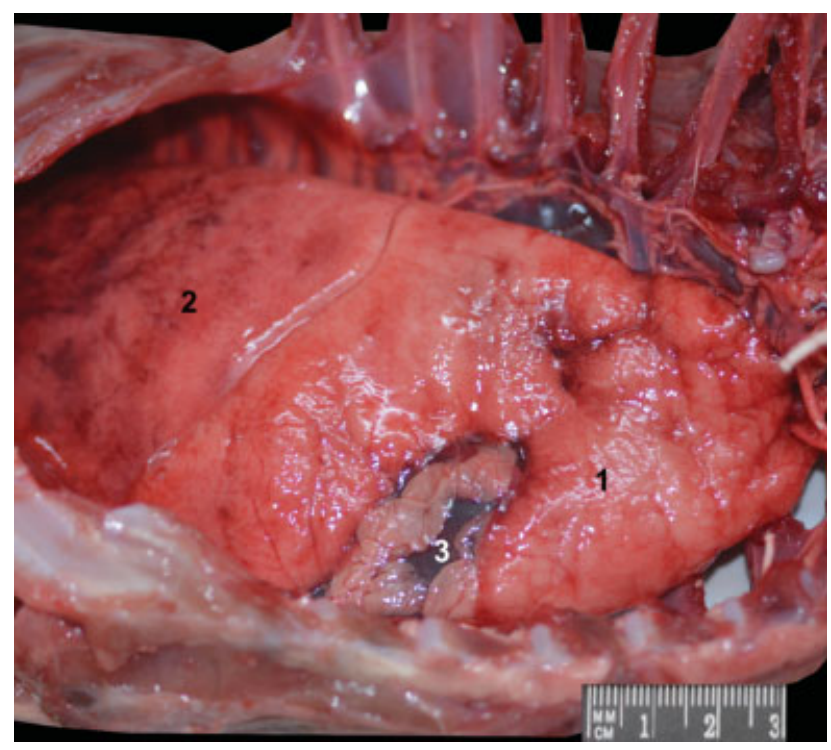

Fig. 4 Right lateral view of the thorax after the removal of the ribs. 1: caudal lobe of the lung; 2 : cranial lobe of the lung; 3 : heart.

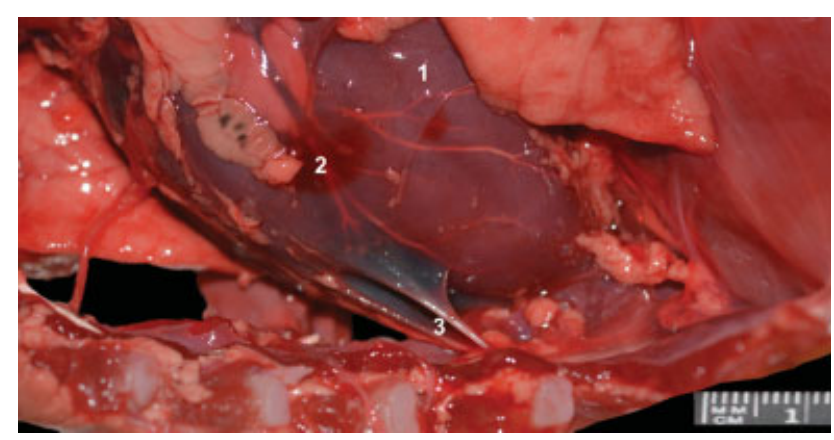

Fig. 5 Left lateral view of the thorax of the pampas deer. 1: left ventricle; 2: paraconal artery; 3 : double sternopericardial ligament.

atrium, the openings of the cranial and caudal vena cava were observed, and between both there was an underdeveloped intervenous tubercle. The coronary sinus was also observed. In the left atrium there were 4-5 pulmonary veins.

The right ventricle received blood from the right atrium through the right atrioventricular ostium. This ventricle

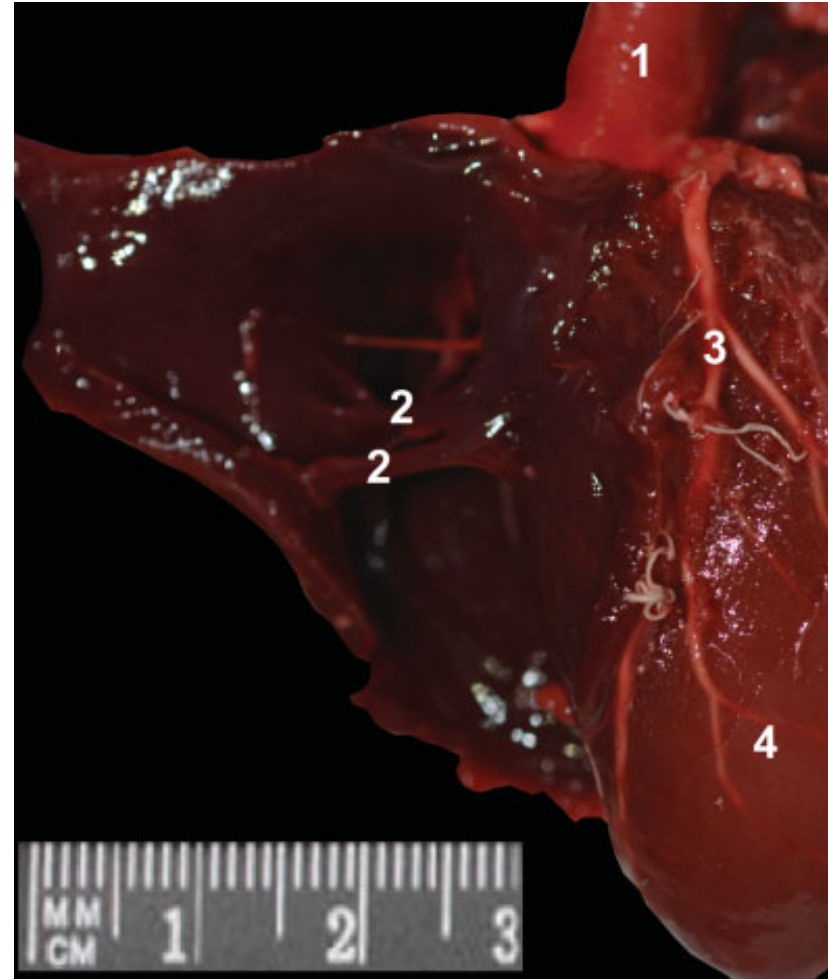

Fig. 6 Right side view of the heart. 1: aorta artery; 2: right septomarginal trabeculae; 3 : subsinuosal artery; 4: left ventricle.

was not part of the apex of the heart. Three papillary muscles (subarterial, parvi and magnus) were projected in its interior. These muscles attached to the chordae tendineae that were part of the tricuspid valve. The papillary magnus muscle was located on the septal wall and was connected by the right septomarginal trabecula to the subarterial papillary muscle. No cartilage or bones were observed in the structure of the cardiac skeleton. Two welldeveloped septomarginal trabeculae were observed in this ventricle ( - Fig. 6). Blood flowed from this ventricle to the pulmonary trunk, passing through the pulmonary semilunar valve ( - Fig. 7). The supraventricular crest was welldeveloped (-Fig. 7). The trabeculae carneae were very poorly-developed in both ventricles, and their walls were almost smooth (-Fig. 7).

The left ventricle received blood from the corresponding atrium, passing through the mitral or bicuspid valve. In this ventricle, both papillary muscles were located on the marginal wall. Two septomarginal trabeculae came out from the subpapillary auricular muscle. This ventricle sent blood to the aorta artery, passing through the aortic semilunar valve. The vestigial ductus arteriosus remained in the adult, forming the ligament arteriosus, and it joined the pulmonary trunk with the aorta artery (-Fig. 8).

The heart was irrigated by the coronary arteries. The left coronary artery was the largest one, and its main branch was the paraconal interventricular branch (-Fig. 9), which crossed the homonymous groove and reached the apex. Then, the left coronary artery continued as the circumflex branch (-Fig. 9) that followed the coronary sulcus toward 


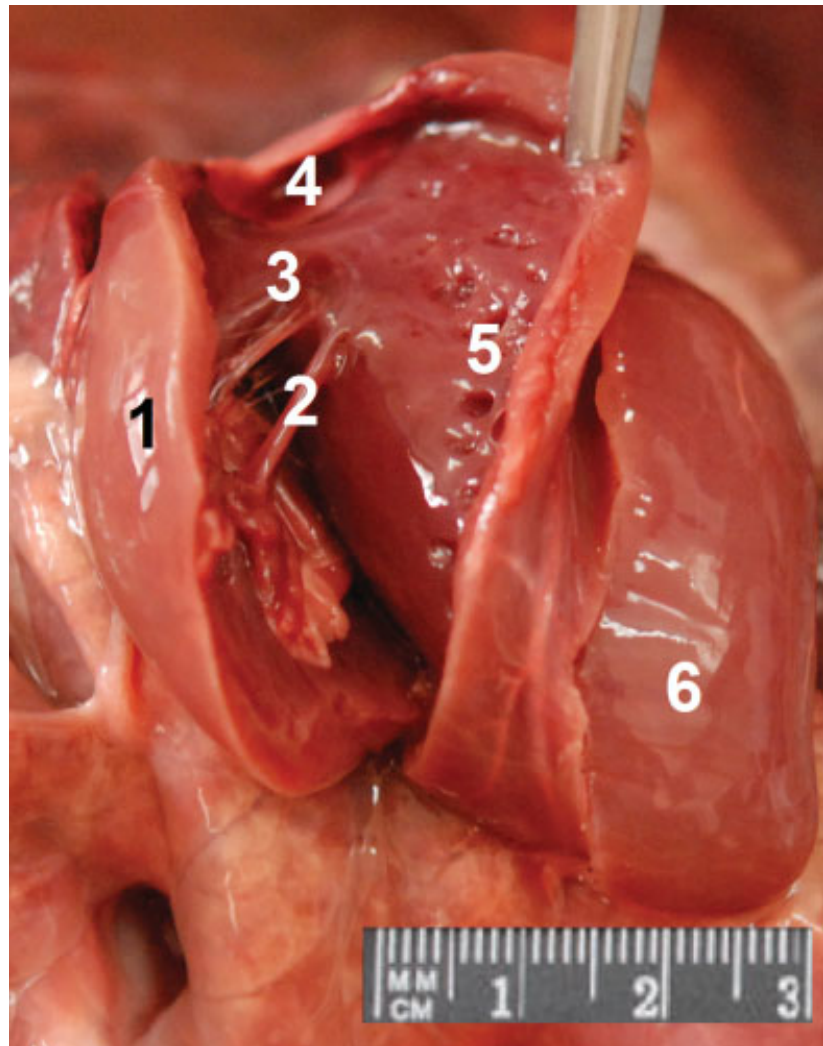

Fig. 7 Left side view of the heart, with the right ventricle incised. 1: right ventricle; 2 : right septomarginal trabeculae; 3 : supraventricular crest; 4: pulmonary semilunar valve; 5 : trabeculae carneae; 6 : left ventricle.

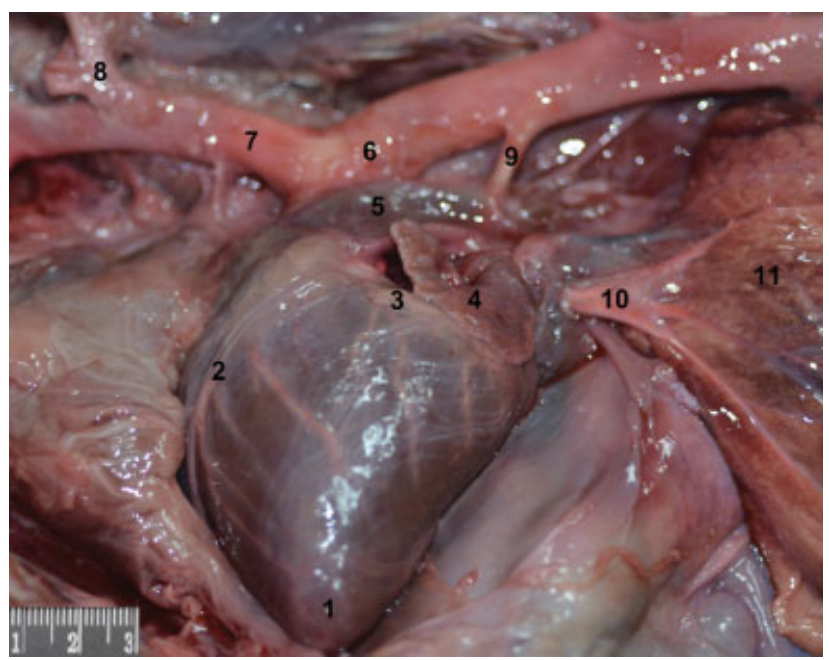

Fig. 8 Ventrolateral left thorax view of the pampas deer. 1: left ventricle; 2: paraconal artery; 3 : circumflex artery; 4: left atrium; 5: pulmonary trunk; 6: aorta artery; 7: brachiocephalic trunk; 8: subclavian artery; 9: ligamentum arteriosum; 10: pulmonary artery; 11: lung.

the caudal face of the heart, and ended before reaching the subsinuosal groove. The right coronary artery reached the coronary sulcus after passing between the left atrium and the pulmonary trunk, continuing in the subsinuosal sulcus (-Fig. 10). There were no anastomoses among the visible

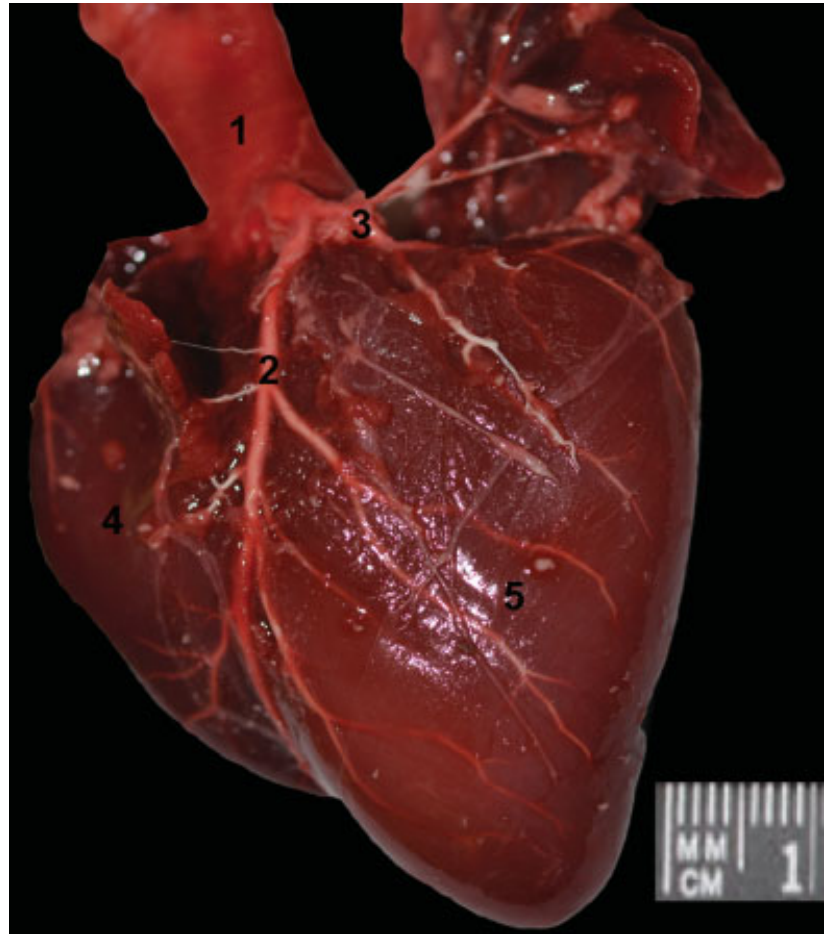

Fig. 9 Left side view of the pampas deer heart. 1: aorta artery; 2: paraconal artery; 3: circumflex artery; 4: right ventricle; 5 : left ventricle.

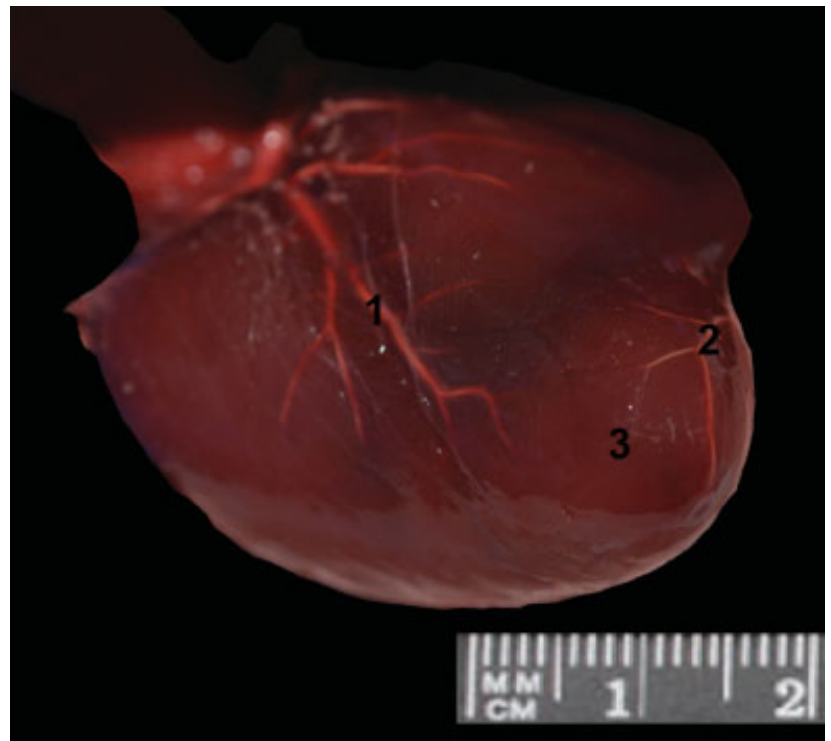

Fig. 10 Ventral view of the apex of the heart of the pampas deer. 1: subsinuosal artery; 2: paraconal artery; 3: apex.

branches of the coronary arteries ( $\mathbf{- F i g . 1 0 )}$ ). Venous blood was overturned into the coronary sinus in the right atrium through the cardiac magna vein.

\section{Discussion}

The present paper describes the main aspects of the external and internal cardiac anatomy of the pampas deer. The 
position of the heart, with a $45^{\circ}$ axis, the presence of a double sternopericardial ligament, and the bilateral cardiac circulation were among the notable findings.

The position of the heart inside the thoracic cavity fits the shape of the thorax. In the pampas deer, the axis of the heart presented an angle of $45^{\circ}$; in domestic ruminants and equines, the heart axis approaches $90^{\circ},{ }^{18}$ and in canines, it approaches $40^{\circ} .{ }^{19}$ In the pampas deer, like what is described for the axis deer (Axis axis), the heart extends from the third intercostal space to the sixth rib. ${ }^{20}$

In the pampas deer, the wide cardiac notch of the lung allowed the heart, mainly on the left side, to have ample contact with the costal wall. This provides a good surface for the semiological examination and an eventual intracardiac injection.

The pampas deer had a cranial sternopericardial ligament and a caudal one. The same disposition is described in domestic ruminants. ${ }^{18}$ The axis deer has two sternopericardial ligaments and one phrenicopericardial ligament. ${ }^{20}$ In canines and equines, only the phrenicopericardial ligament is well-developed. ${ }^{18,19}$

Septomarginal trabeculae are structures that are part of the conduction system of the heart. In the pampas deer, in the right ventricle, the presence of a well-developed Yshaped septomarginal trabecula was observed. In domestic ruminants, the presence of a simple septomarginal trabecula in this ventricle has been described. ${ }^{19}$ In the study conducted by Cope, ${ }^{21}$ there was a wide variability in the shape of this trabecula in the canines analyzed.

In the zone of expulsion of the ventricles (mainly the right one) of the heart of domestic animals, the presence of carneae trabeculae has been described ${ }^{18,19}$; they help increase cardiac contraction, and were very underdeveloped in both ventricles in the pampas deer.

In the heart of the pampas deer, we did not observe the presence of a cardiac bone or cartilage, but histological studies are required to corroborate this finding. The presence of a cardiac bone has been described in cattle and sheep. ${ }^{22,23}$

Frink and Merrick ${ }^{24}$ described the presence of a cardiac bone in the atrial septum of the 25 sheep in their study, and they occasionally found a second bone.

The arteries and veins of the heart of domestic animals vary widely in different species, and even among individuals of the same species. The vessels are in the different grooves of the heart, protected by connective tissue, to be able to accompany the physiological variations of the organ and avoid suffering torsions or too much tension. ${ }^{25}$

In domestic animals, the arterial supply of the heart comes from two coronary arteries (right and left), but they do not have the same importance in every species. In the pampas deer, the left coronary artery forms the paraconal and circumflex branches, while the right coronary artery forms the subsinuosal branch. With a shared coronary irrigation, the pampas deer has bilateral circulation. In sheep, cattle and marsh deer, the left coronary artery is soon divided, forming the paraconal and circumflex arteries. ${ }^{24,26,27}$ In sheep and roe deer, the circumflex artery forms the subsinuosal branch., 7,27 Pigs also have bilateral circulation, while horses have right circulation. ${ }^{19,28}$ The venous drainage of the heart is similar in pampas deer, roe deer and sheep. ${ }^{18,29}$

\section{Conclusion}

In conclusion, most differences between the hearts of pampas deer and those of domestic animals are subtle, notably the obliquity of the organ, the absence of a cardiac bone, and the bilateral irrigation. With other techniques, histological, semiological and physiological studies must be performed in order to better understand the anatomy and physiology of the heart of this species.

\section{Conflicts of Interest}

The authors have none to disclose.

\section{Acknowledgements}

We would like to thank to Dr. Rodolfo Ungerfeld and Intendencia Departamental de Maldonado (IDM) for providing the facilities to conduct the research with the animals of the ECFA.

\section{References}

1 González S, Maldonado JE, Leonard JA, et al. Conservation genetics of the endangered Pampas deer (Ozotoceros bezoarticus). Mol Ecol 1998;7(01):47-56. Doi: 10.1046/j.1365-294x.1998.00303.x

2 González S, Cosse M, Góss Braga F, et al. Ozotoceros bezoarticus (Linnaeus 1758). Capítulo 12. In: Duarte JMB, González S. Neotropical Cervidology: Biology and Medicine of Latin American Deer. Editorial: Funep, Jaboticabal; 2010:393

3 Hill AJ, Iaizzo PA. Comparative cardiac anatomy. In: Handbook of cardiac anatomy, physiology, and devices. Springer, Cham; 2015: 89-114

4 Depreux R, Mestdagh H, Houcke M. [Comparative morphology of the trabecula septomarginalis in terrestrial mammals]. Anat Anz 1976;139(1-2):24-35

5 Noestelthaller A, Probst A, Koenig HE. Use of corrosion casting techniques to evaluate coronary collateral vessels and anastomoses in hearts of canine cadavers. Am J Vet Res 2005;66(10): 1724-1728. Doi: 10.2460/ajvr.2005.66.1724

6 Ozbag D, Gumusalan Y, Demirant A. The comparative investigation of morphology of papillary muscles of left ventricle in different species. Int J Clin Pract 2005;59(05):529-536. Doi: 10.1111/j.1742-1241.2004.00345.x

7 Frackowiak H, Jasiczak K, Pluta K, Godynicki S. Coronary arteries of the roe deer (Capreolus capreolus; Linnaeus 1758) heart. Pol J Vet Sci 2007;10(02):105-108

8 Erdoğan S, Pérez W. Arterial vascularization and morphological characteristics of adrenal glands in the Pampas deer (Ozotoceros bezoarticus, Linnaeus 1758). Anat Histol Embryol 2014;43(05): 369-374. Doi: 10.1111/ahe.12085

9 Pérez W, Erdoğan S. Arterial thoracic vascularization in some deer species: pampas deer (Ozotoceros bezoarticus), brown brocket deer (Mazama gouazoubira) and axis deer (Axis axis). Anat Histol Embryol 2014;43(06):490-494. Doi: 10.1111/ahe.12102

10 Magariños L, Benech Gulla A, Vazquez N, Pérez W. Aspectos Macroanatómicos del Corazón del Carpincho (Hydrochoerus hydrochaeris). Int J Morphol 2018;36(01):235-242. Doi: 10.4067/S0717-95022018000100235

11 Pérez W, Méndez V, Vazquez N, Navarrete M, König HE. Gross anatomy of the heart of the alpaca (Vicugna pacos, Linnaeus 1758). Anat Histol Embryol 2018;47(02):110-118. Doi: 10.1111/ ahe. 12327 
12 Vazquez N, Dos Santos D, Pérez W. Arterial irrigation of the head and neck of the pampas deer (Ozotoceros bezoarticus, Linnaeus 1758). Anat Sci Int 2018a;93(04):540-547. Doi: 10.1007/s12565018-0448-8

13 Vazquez N, Ríos C, Sorriba V, Pérez W. Arterial distribution to the pelvic cavity and pelvic limb in the pampas deer (Ozotoceros bezoarticus, Linnaeus 1758). Anat Histol Embryol 2018b;47(02): 133-139. Doi: 10.1111/ahe.12331

14 Pérez W, Vazquez N, Ungerfeld R. Gross anatomy of the female genital organs of the pampas deer (Ozotoceros bezoarticus, Linnaeus 1758). Anat Histol Embryol 2013a;42(03):168-174. Doi: $10.1111 / \mathrm{j} .1439-0264.2012 .01180 . \mathrm{x}$

15 Pérez W, Vazquez N, Ungerfeld R. Gross anatomy of the male genital organs of the pampas deer (Ozotoceros bezoarticus, Linnaeus 1758). Anat Sci Int 2013b;88(03):123-129. Doi: 10.1007/s12565-013-0171-4

16 Pérez W, Vazquez N, Ungerfeld R. Arterial Vascularization of the Gastrointestinal Tract of the Pampas Deer (Ozotoceros bezoarticus, Linnaeus, 1758). Anat Histol Embryol 2016;45(03):240-245. Doi: $10.1111 /$ ahe. 12192

17 International Committee on Veterinary Gross Anatomical Nomenclature, and International Committee on Veterinary Gross Anatomical Nomenclature. Nomina anatomica veterinaria. Knoxville: World Association on Veterinary Anatomist; 2017:166

18 Barone R. Anatomie comparée des mammifères domestiques: Tome 5, angiologie. France: Vigot; 2011

19 Nickel R, Schummer A, Seiferle E. The anatomy of the domestic animals. Vol. 3. Berlin-Hamburg: Verlag Paul Parey; 2005

20 Kumar Shil S, Ferdows S, Chandra Sutradhar B, Chandra Das B. Topographic Anatomy of Visceral Organs of a Spotted Deer (Axis axis). Short communication. Research Journal for Veterinary
Practitioners 2014;2(04):55-57. Doi: 10.14737/journal.rjvp/ 2014/2.4.55.57

21 Cope LA. Morphological Variations in the Canine (Canis familiaris) Right Ventricle Trabecula Septomarginalis Dextra and a Proposed Classification Scheme. Anat Histol Embryol 2016;45(06): 437-442. Doi: 10.1111/ahe.12217

22 James TN. Anatomy of the sinus node, av node and os cordis of the beef heart. Anat Rec 1965;153(04):361-371. Doi: 10.1002/ ar.1091530405

23 Mohammadpour AA, Mourad A. Morphological study of the heart and os cordis in sheep and goat. Indian Vet J 2007;84(03):284-287

24 Frink RJ, Merrick B. The sheep heart: coronary and conduction system anatomy with special reference to the presence of an os cordis. Anat Rec 1974;179(02):189-200. Doi: 10.1002/ ar.1091790204

25 Habermehl KH. Morphologie und funktion der Herzegengefalie. Aus dem Veterinar-Anatomischen Institut der Universitat Zurich; 1965:111-138

26 Bhargava I, Beaver C. Observations on the arterial supply and venous drainage of the bovine heart. Anat Anz 1970;126(04): 343-354

27 Fernandes Machado MR, Moreira Borges E, Singaretti Oliveira F, Filippini-Tomazini M, Peres Ferraz de Melo A, Barbanti Duarte JM. Intramyocardial course of the coronary arteries in the marsh deer (Blastocerus dichotomus). Braz J Vet Res Anim Sci 2002;39(06): 285-287. Doi: 10.1590/S1413-95962002000600002

28 Sabathie LG, Pianetto MB. The coronary arteries of the horse. Rev Argent Cardiol 1942;8:184

29 Kabac M, Onuk B. Macroanatomic Investigations on the Venous Drainage of the Heart in Roe Deer (Capreolus capreolus). Kafkas Univ Vet Fak Derg 2012;18(06):957-963. Doi: 10.9775/kvfd.2012.6841 